\title{
The Not-So-Dark Ages: Ecology for Human Growth in Medieval and Early Twentieth Century Portugal as Inferred From Skeletal Growth Profiles
}

\author{
Hugo F.V. Cardoso ${ }^{1,2 \star}$ and Susana Garcia ${ }^{3}$ \\ ${ }^{1}$ Departamento de Antropologia \& Centro de Investigação em Antropologia e Saúde, Universidade de Coimbra, \\ 3000-056 Coimbra, Portugal \\ ${ }^{2}$ Faculdade de Medicina, Universidade do Porto, 4200-319 Porto, Portugal \\ ${ }^{3}$ Instituto Superior de Ciências Sociais e Políticas \& Centro de Administração e Políticas Públicas, \\ Universidade Técnica de Lisboa, Pólo Universitário do Alto da Ajuda, 1300-663 Lisboa, Portugal
}

KEYWORDS $\quad$ growth patterns; child labor; urbanization; industrialization; living conditions

\begin{abstract}
This study attempts to address the issue of relative living standards in Portuguese medieval and early 20th century periods. Since the growth of children provides a good measure of environmental quality for the overall population, the skeletal growth profiles of medieval Leiria and early 20th century Lisbon were compared. Results show that growth in femur length of medieval children did not differ significantly from that of early 20 th century children, but after puberty medieval adolescents seem to have recovered, as they have significantly longer femora as adults. This is suggestive of greater potential for catch-up growth in medieval adolescents. We suggest that this results from distinct child labor practices, which impact differentially on the growth of Leiria and Lisbon adolescents. Work for medieval children and adolescents were related to family activ-
\end{abstract}

There is a European traditional view of history which depicts the medieval period as the "Dark Ages." The concept seems to have been created because the Middle Ages have been seen as a religiously dominated period of social decline, antiscience, and of brutish and miserable peasant life, although historians and archaeologists have done much to discredit such image. However, could the Middle Ages have been more detrimental for human health than the unhygienic and overcrowded conditions and spread of communicable diseases, brought about by increased urbanization and industrialization of the 19th and 20th century? Industrialization has embodied the notion of progress, characterized by unprecedented economic growth, the factory system of production based on artificially powered machines, and by the ability to produce more than was needed to sustain a large percentage of the population. Yet, living conditions during the Industrial Revolution deteriorated for a large percentage of the population, socioeconomic disparities increased, and people were at greater risk of malnutrition and infection. Evidence has accumulated that living conditions of Europeans actually declined progressively from the late Middle Ages to the early industrial revolution (Lewis, 2002; de Beer, 2004; Steckel, 2004; KemkesGrottenthaler, 2005; Maat, 2005).

The main source of evidence for such a change in living conditions since the Middle Ages is past human stature and growth patterns reconstructed from skeletal remains in bioarchaeological studies. The use of growth ities, and care and attention were provided by family members. Conversely, in early 20th century Lisbon children were more often sent to factories at around 12 years of age as an extra source of family income, where they were exploited for their labor. Since medieval and early 20th century children were stunted at an early age, greater potential for catch-up growth in medieval adolescents results from exhausting work being added to modern adolescent's burdens of disease and poor diet, when they entered the labor market. Although early 20th century Lisbon did not differ in overall unfavorable living conditions from medieval Leiria, after puberty different child labor practices may have placed modern adolescents at greater risk of undernutrition and poor growth. Am J Phys Anthropol 000:000-000, 2008. ๑2008 Wiley-Liss, Inc.

and stature data to infer variations in the standard of living relies on the assumption that the rate of growth of the individuals of any population and their final attained height reflect sanitary conditions, nutritional quality, amount of energy expenditure, and overall health during childhood (Tanner, 1982; Susanne, 1984; Fogel, 1986; Schell, 1989; Bogin, 1999; Mays, 1999). The Middle Ages have also been traditionally viewed as a particularly difficult period for children and childhood. This view has been brought about largely by the influence of Ariès (1962). According to Ariès, medieval children were largely ignored and were viewed as, essentially, small and inadequate adults. Children's lives were perilous,

\footnotetext{
Grant sponsor: Fundação para a Ciência e Tecnologia, Portugal; Grant number: SFRH/BPD/22142/2005.

\begin{abstract}
*Correspondence to: Hugo F.V. Cardoso, Departamento de Antropologia, Universidade de Coimbra, Rua do Arco da Traição, 3000056 Coimbra, Portugal. E-mail: hcardoso@antrop.uc.pt
\end{abstract}

Received 14 November 2007; accepted 26 March 2008

DOI 10.1002/ajpa.20910

Published online in Wiley InterScience

(www.interscience.wiley.com). 
TABLE 1. Breakdown of the Leiria and Lisbon samples by age group and distribution of individuals in the Lisbon sample by decade of birth

\begin{tabular}{|c|c|c|c|c|c|c|c|c|c|}
\hline \multirow[b]{2}{*}{ Age groups } & \multirow[b]{2}{*}{ Leiria } & \multicolumn{8}{|c|}{ Lisbon } \\
\hline & & 1900-1909 & 1910-1919 & 1920-1929 & 1930-1939 & 1940-1949 & 1950-1959 & $>1959$ & Total \\
\hline $0.0-0.9$ years & 5 & - & 2 & 2 & - & 1 & 3 & 1 & 9 \\
\hline $1.0-4.9$ years & 6 & 2 & 1 & 7 & 4 & 6 & 12 & - & 32 \\
\hline $5.0-12.9$ years & 14 & 2 & 2 & 9 & 2 & 6 & 6 & - & 27 \\
\hline Total (subadults) & 25 & 4 & 5 & 18 & 6 & 13 & 21 & 1 & 68 \\
\hline $18.0-29.0$ years & 10 & 18 & 6 & 14 & 7 & 6 & - & - & 51 \\
\hline $30.0-49.0$ years & 23 & 26 & 6 & 6 & 4 & - & - & - & 42 \\
\hline$>50.0$ years & 14 & 8 & 10 & - & - & - & - & - & 18 \\
\hline Total (adults) & 47 & 52 & 22 & 20 & 11 & 6 & - & - & 111 \\
\hline
\end{tabular}

rough, and hard, where disease, poor diet, and neglect took their toll. Although Ariès' theory has been disputed by social historians (e.g., Shahar, 1990; Oliveira, 2007) over the years, the only study which actually provides direct evidence for a decline in childhood health from the medieval to the early industrial period is Lewis (2002). In this study, subadult skeletons from medieval and post-medieval English archaeological sites were compared and it was found that the industrial London sample showed retarded growth, higher levels of stress, and a greater prevalence of metabolic and infectious disease compared with the rural and urban medieval samples.

Comparing the growth rate between two, or more, archaeological samples of immature skeletal remains involves the construction of a skeletal growth profile (SGP) to examine the cross-sectional age-progressive trend in growth (Hoppa, 2000). In SGPs, a proxy for statural growth such as a long bone measurement, usually femur length, is plotted against a measure of chronological age, such as dental age. The basic assumption is that dental development is less sensitive to environmental insults and thus considered the best indicator of chronological age, whereas skeletal development is more affected and thus provides a measure of growth faltering and health differentials (Saunders et al., 1993; Hoppa, 1992, 2000; Cardoso, 2007a). Under stressed environmental conditions, a large number of individuals will show a bone growth deficit relative to dental age, and this relative difference indicates a delay in skeletal growth which has been interpreted as the result of environmental effects. The demonstration of differential growth between samples is used as evidence for differential health status between entire populations, either temporally or geographically (Johnston and Zimmer, 1989; Saunders, 1992, 2000).

This study addresses the question of whether the Portuguese Middle Ages were a period of miserable living conditions when compared with the period of increased urbanization associated with industrialization. This was carried out by comparing the skeletal growth profile of a sample of children from a late medieval cemetery in Leiria with that of a sample of identified subadult skeletal material from early 20 th century industrial Lisbon. Although Portugal experienced a late and incipient industrial revolution, the city of Lisbon supported a large services sector and small industries of traditional and manufacture level, and the urban growth of the city was greatest during the first half of the 20th century, because of migration movements of poor rural people who fled their home town in search of jobs and a better standard of living. The expectation is to detect greater deficits in the growth of early 20th century children as a result of poor health and living conditions, malnutrition and greater socioeconomic disparities associated with increased urbanization and industrialization, in spite of the supposed lower standard of living during the Middle Ages. Although the samples are separated by over 500 years of history, there are no reasons to believe that genetic factors play a significant role in growth differences.

\section{MATERIALS AND METHODS The samples}

Two samples of subadult skeletons were chosen for their sizes, good overall state of preservation, and contrasting population types. The late medieval sample utilized comprises the skeletal remains of 157 individuals, excavated from the urban medieval churchyard associated with the São Martinho Church in Leiria, central Portugal. This church was built around 1211 and destroyed between 1549 and 1553 (Gomes, 1990). Presumably, the burials, which have been excavated from this cemetery, date to this period of time. The 1211-1553 chronology was subsequently confirmed by archaeological findings (e.g., coins) and radiocarbon analysis (Garcia, 2007). During the excavation, a considerable amount of disarticulated skeletal material was recovered, but only fully articulated skeletons, representing single complete burials, were analyzed. Because of preservation, only 47 adult (18 females and 29 males) and 25 subadult skeletons were used in this study. Only skeletons whose dental age has been estimated above 18 years and whose long bones showed complete epiphyseal union were included in the adult segment of the Leiria sample. A breakdown of the Leiria sample by age groups can be seen in Table 1. The Leiria subadults were retrieved from the same cemetery as the adults and no separate area for their burial was identified during the excavation. Additionally, no preferential treatment was given to child burials. Historical documents also point to a very heterogeneous population in the $S \tilde{a} o$ Martinho area, with all social classes being represented, including members of the local aristocracy (Gomes, 1990).

The Leiria series typifies the urban medieval period in Portugal, contemporaneous with the establishment and consolidation of the kingdom of Portugal (1143) and later with the early Age of Discoveries. Despite the occasional famine outbreak and armed conflict, particularly with the neighboring kingdom of Castela, the Portuguese Middle 
Ages were a period of territorial stability and relative economic efficiency given the country's isolation (Magalhães, 1993; Mattoso, 1993). Leiria, in particular, seems to have been a relatively prosperous town during the Middle Ages. It was very dynamic commercially and many service sector activities were established there, particularly in the area surrounding the São Martinho church. An indication of Leiria's prosperity is house rent prices in the main streets, which were considerably high compared with those of other medieval Portuguese towns and cities, including the capital city Lisbon (Gomes, 1990). Besides its commercial activity, this town area was also very attractive due to the proximity of a permanent water source, the Lis River. The land around Leiria was and still is one of the richest in the country, which was the basis of its agricultural production and overall prosperity. Greater agricultural production, easy access to water sources, and wider distribution of goods must have contributed to improved medieval diets of the Leiria people. Medieval historians suggest that medieval diet was both diverse and rich in fresh products (Gonçalves, 2004). The exact size of the Leiria population during this period is unknown, but several indirect sources point to increasing numbers between 1200 and 1500. Rural migration was particularly intense after the Black Plague of 1348/1349 when there was a high demand for manual labor in urban areas. Around the year 1700, the population size of Leiria was documented as 3,500 souls (Lima, 1736). Considering that Leiria was an important Portuguese medieval town, the best guess for the population size of Leiria during the Middle Ages, would be between 1000 and 3000 .

The Lisbon collection represents the early 20th century densely urbanized/industrial sample and it comprises a series of approximately 700 fully identified skeletons obtained from public cemeteries in the Lisbon area between 1981 and 2003 (Cardoso, 2006). A total of 68 subadult and 111 adult (53 females and 58 males) skeletons were utilized. Given the wide interval of years of birth in the collection (1805-1972) and to control for potential secular trend effects on stature, the adults and subadults were selected to insure that they did not belong to different birth cohorts. Although the adult and subadult segments of the Lisbon sample are not entirely of the same birth cohorts, the distribution of birth years do not show any significant differences $\left(\chi^{2}=3.51, P<\right.$ 0.74 , df $=6$ ), with the majority of birth dates falling between 1900 and 1950. Table 1 shows the distribution of individuals in the Lisbon sample by age group and birth decade.

The Lisbon children embody the increased urbanization and industrialization of the Portugal's capital city during the early republican and dictatorship years. Established as a republic state in 1910, Portugal experienced civil unrest until the rise of a dictatorship in 1933. It was not until 1974, with a military coup, that the shift from a dictatorial government to a democratic pluralist political system took place. As Portugal's capital city, Lisbon witnessed and experienced the most important political events and economical developments. Portugal emerged from the 19th century as a declining world political power, with a fragile agricultural system, incomplete industrialization, a weak capitalist system, and a centralized and strong catholic church. During most of the dictatorship years, Portugal remained a very isolated, underdeveloped and traditional society, where social and economic conditions of the late 19th century largely prevailed. The majority of farmers were still practicing subsistence agriculture with little motivation for the establishment of industrial and capitalist economies (Giner, 1982). During the 20th century, the decrease in the population working in the primary sector was not so much a consequence of increased productivity in the secondary sectors, but of increased migration to urban centers and employment in the tertiary sector (Maia, 2001). Only the major urban centers, such as Lisbon, had significant industries, but the majority of them were small and of traditional sectors. The industrial labor force was also predominantly illiterate, with few or no technical skills, supported by women and child work and with no free association rights. The Lisbon area was the region of greatest population growth in absolute terms. On one hand, being the country's capital, it housed much of the governmental institutions, and on the other, it also comprised the most important manufacturing and service sector jobs. The city's population increased roughly threefold between 1890 and 1960, from approximately 300,000 inhabitants to more than 800,000 (Baptista and Rodrigues, 1995). Lisbon, however, was one of the Portuguese cities with the lowest birth rates, and urban growth was accomplished almost solely at the expense of rural migration (Paúl, 1945).

\section{Data collection and analysis}

To compare growth status of the Leiria children with that of the Lisbon children, cross-sectional skeletal growth profiles (SGP) were constructed for each sample, using growth in femur length as a measure of statural growth and growth in tooth length as a measure of age. Tooth length was chosen as the estimate of age because progression in tooth calcification is considered the single best estimator of true chronological age. Tooth length was measured according to the recommendations of Liversidge et al. for use in age prediction (Liversidge et al., 1993; Liversidge and Molleson, 1999), as the distance from the cusp-tip to the developing edge of crown or root in the midline, parallel to the long axis of the tooth. In teeth with more than one cusp or root, the maximum length was measured. All available mandibular deciduous and permanent teeth were measured to the nearest tenth of a millimeter using a digital sliding caliper. In the Leiria sample, only loose teeth were measured and in the Lisbon sample, approximately half of the tooth measurements were obtained from periapical radiographs. Tooth length was measured on the left side only or on the right side if the left was unavailable. Radiographs in the Lisbon sample were taken in relation to the lingual-buccal plane with the aid of an extension cone paralleling film-holding instrument and with a 10 $\mathrm{mm}$ metal bar attached to the specimen to provide a gauge to assess image magnification. Because tooth length measured on radiographs is used as a surrogate for actual tooth length in the Lisbon sample, it was important to assess whether the two measurements differ significantly. Twenty isolated uniradicular deciduous and permanent teeth, six isolated multiradicular deciduous teeth, and twenty isolated multiradicular permanent teeth were measured directly and then replaced in their sockets, where they were radiographed. Differences between direct and radiographic measurements were compared using a paired $t$-test or a Wilcoxon paired-sample test (when comparing multiradicular deciduous teeth) and were never found to be significant $(P>0.10)$ (see also Cardoso, 2007b). 
Femur length provides a simple cumulative measure of physical growth in skeletal samples and since there is a high correlation between stature and femur length ( 0.8) (e.g., Pearson, 1899; Trotter and Gleser, 1952; Ruff, 2007); it is considered a proxy for statural growth. Maximum femur length in the adults and femur diaphyseal length in the subadults of both samples were measured to the nearest whole millimeter using an osteometric board. Left femora were measured with replacement by the right if the left was unavailable or poorly preserved. To insure comparability of data in SGPs across the different age groups, only femora with unfused proximal and distal epiphysis were measured. Although epiphyseal union in the femur can occur beyond the age of 13 years, our samples include preadolescent individuals only, selected on the basis of dental age estimates as all skeletons below the age of 12.9 years. Because sex cannot be easily determined in the unidentified prepubertal skeletons of the Leiria sample, samples were pooled with regards to sex. Since most of the sex differences in body size are due to the events of puberty (Tanner, 1989; Bogin, 1999), pooling male and female growth curves is not likely to increase significantly the variation of the growth profiles, even if one sex outnumbers the other.

Two approaches were used to construct SGPs. In the first approach, femur length was plotted against absolute tooth lengths to construct the SGP and this enabled growth comparisons between samples to be made tooth by tooth (length) and not by an overall single dental age. Because tooth length is a continuous variable, it avoided unnecessary complications from building femur growth profiles with tooth calcification stages, which are discrete variables. In addition to tooth length being preferred relative to tooth formation stages, due to the latter being a discrete trait and also subjected to higher subjectivity of assessment, the greatest advantage of using absolute tooth length is that femur growth occurs as a near-linear function of tooth length. Visual inspection of the scatter plots was the basis for establishing a near-linear relationship between femur length and tooth length, which was subsequently confirmed when nonlinear regressions were fitted to the data. Since each SGP is built tooth by tooth, the relationship between femur length and the length of any tooth represents a near-linear fraction of a nonlinear relationship represented by the whole growth period. In cross-sectional samples, the relationship between femur length and dental age is approximately linear between birth and 2 years of age and then between 2 and 18 years.

Because teeth were considered individually, some SGPs provided very small sample sizes, particularly with the Leiria series. Consequently, some SGPs were subsequently eliminated from the analysis, namely those whose femur length was plotted against the deciduous central incisor and the permanent third molar, second premolar, and lateral incisor. Once femur diaphyseal length was plotted against tooth length, simple linear regression equations were fit to data points of each sample (Leiria and Lisbon) and compared. Since femur growth occurs as a near-linear function of tooth length, simple analysis of covariance (ANCOVA) was employed to compare the slopes and elevations of the two samples' regression lines. First the ANCOVA was carried out including the interaction term between the covariate (sample) and the independent variable (tooth length). If statistically significant, the slopes were considered differ- ent and the elevations could not be compared. If differences between slopes were nonsignificant, the interaction term was removed and the ANCOVA rerun. If results were statistically significant, the elevations were considered different. Differences between elevations are the basis for concluding differences in femur length between samples. Because of small sample sizes in the Leiria sample, after the ANCOVA was performed, the residuals were examined for signs of non-normality in each SGP. Normal probability plots approximated straight lines and did not show significant departures from normality, except with the first permanent molar. Homocedasticity of $\mathrm{Y}$ variables for each SGP was also examined using Levene's test for equality of variances. Heterocedasticity of femur length was only detected when age was estimated from the length of the deciduous canine.

In the second approach, femur length was plotted against an overall mean dental age to construct the SGP for each sample. Dental age was calculated for each skeleton as the mean age obtained from all available teeth using Liversidge and coworkers' prediction equations for the deciduous (Liversidge et al., 1993) and permanent dentition (Liversidge and Molleson, 1999). Given the nonlinear relationship of dental age with femur length, fourth-degree least-square polynomial regression equations were calculated for each sample and compared. A polynomial analysis of covariance (ANCOVA) was employed to compare the two samples. Similarly to the previous approach, the homogeneity of covariate-dependent variable slopes was tested and if nonsignificant, the analysis was rerun without the interaction term, after which the growth curves were considered different if statistically significant results were obtained. The approach followed here is similar to that of Pinhasi et al. (2005, 2006). Residuals in the second approach were examined and did not show significant departures from normality. Levene's test for equality of variances also demonstrated homocedasticity of the $\mathrm{Y}$ variable for each SGP. All statistical analyses were performed with the statistical package STATISTICA.

The Leiria and Lisbon samples were also compared with a better nourished population to assess the amount of growth deficit in both samples. This was achieved by computing individual $z$-scores. $Z$-scores are calculated by subtracting from every observed femur length the mean of a reference sample and dividing by the standard deviation, for the appropriate age. The nineteenth century church cemetery sample from Belleville, Ontario, (Saunders et al., 1993) was chosen as the reference data, since it has been shown to represent a well-nourished population by comparison with the modern Denver Growth Study data (Maresh, 1970). Because sex in the Leiria sample is not known and the Lisbon subadults are treated as if sex is also unknown, this archaeological sample was also considered more suitable to calculate $z$ scores, since it provides age appropriate femur length data which are not sex-specific. Other than comparing SGPs between the Leiria and Lisbon samples, differences in adult femur length between the two samples were also compared via a $t$-test. This comparison was carried out to demonstrate whether any differences in size between samples in the preadolescent years are passed on to the adults and evaluate possible differences in growth during the adolescent years. The Lisbon and Leiria adults were also compared with the Belleville adults via a $t$-test to assess the amount of deficit in adult femur length in both Portuguese samples. 
TABLE 2. Comparison between Leiria (medieval) and Lisbon (early 20th century) regression coefficients when femur diaphyseal length is regressed on tooth length

\begin{tabular}{|c|c|c|c|c|c|c|c|c|c|c|c|c|c|c|c|c|}
\hline \multirow[b]{2}{*}{ Tooth } & \multicolumn{7}{|c|}{ Leiria sample } & \multicolumn{7}{|c|}{ Lisbon sample } & \multirow[b]{2}{*}{$F$} & \multirow[b]{2}{*}{$F^{\prime}$} \\
\hline & $\bar{N}$ & $A$ & SE (A) & $b$ & SE (b) & $r^{2}$ & $\overline{\mathrm{SEE}}$ & $\bar{N}$ & $A$ & SE (A) & $b$ & SE (b) & $r^{2}$ & $\overline{\mathrm{SEE}}$ & & \\
\hline $\mathrm{m} 2$ & 5 & 29.53 & 14.20 & 15.13 & 3.65 & 0.80 & 6.23 & 10 & 7.66 & 11.92 & 18.46 & 2.24 & 0.88 & 8.16 & 0.45 & 2.94 \\
\hline $\mathrm{m} 1$ & 4 & 52.39 & 5.34 & 6.54 & 1.17 & 0.91 & 1.51 & 7 & 46.87 & 11.34 & 8.65 & 2.38 & 0.70 & 6.00 & 0.22 & 1.58 \\
\hline $\mathrm{C}$ & 6 & 48.19 & 2.28 & 8.09 & 0.20 & 0.99 & 2.89 & 26 & 64.23 & 5.32 & 6.99 & 0.46 & 0.90 & 10.43 & 1.85 & 1.34 \\
\hline i2 & 5 & 38.79 & 4.78 & 8.21 & 0.57 & 0.98 & 5.29 & 26 & 39.85 & 6.66 & 8.45 & 0.58 & 0.90 & 12.65 & 0.03 & 0.24 \\
\hline M2 & 7 & 160.09 & 5.01 & 9.89 & 0.45 & 0.99 & 5.90 & 33 & 163.67 & 6.95 & 10.02 & 0.58 & 0.90 & 16.15 & 0.01 & 0.60 \\
\hline M1 & 6 & 127.58 & 9.21 & 6.74 & 0.70 & 0.95 & 7.13 & 36 & 90.17 & 7.72 & 9.98 & 0.69 & 0.86 & 16.25 & 3.85 & 0.10 \\
\hline PM1 & 5 & 117.29 & 11.45 & 11.03 & 0.89 & 0.97 & 8.90 & 42 & 148.48 & 6.32 & 9.73 & 0.51 & 0.90 & 20.01 & 0.42 & 2.88 \\
\hline $\mathrm{C}$ & 11 & 130.05 & 10.98 & 8.28 & 0.82 & 0.91 & 14.49 & 54 & 111.96 & 5.63 & 9.79 & 0.41 & 0.92 & 21.37 & 1.50 & 0.01 \\
\hline I1 & 8 & 110.05 & 22.97 & 7.98 & 1.40 & 0.82 & 27.80 & 50 & 89.89 & 6.05 & 9.82 & 0.44 & 0.91 & 18.76 & 2.38 & 0.85 \\
\hline
\end{tabular}

Femur diaphyseal length is estimated from the equation: $y=A+b \times x$. The standard errors (SE) of $A$ and $b$, the standard error of the estimate (SEE) for regression predictions and the coefficient of determination $\left(r^{2}\right)$ is shown. The homogeneity of the regression slopes $(F)$ and of the elevations $\left(F^{\prime}\right)$ is compared by analysis of covariance (ANCOVA). All differences are statistically insignificant $(P>0.05)$.

Because we wish to infer differences in size from differences in femur length, it is important to note that populations may differ in femur length relative to stature (Ruff, 2002) or lower limb length relative to stature (Bogin and Rios, 2003), and that there are also important changes in such proportions during growth (Buschang, 1982; Bogin, 1999; Ruff, 2007). However, our approach assumes that both samples do not differ genetically and that adult height potential and body proportions are approximately the same in both samples. Although there is no available data that can show whether body proportions have changed significantly in Portugal over the past 800 years, any genetic contribution to the difference in absolute femur length and in femur length relative to stature, between medieval and early 20th century Portuguese, is not possible to assess given that there is no known basis for the genetic determination of body size and shape differences between populations (Bogin et al., 2001). Several peoples (Roman, Germanic, and Berber) occupied the modern Portuguese territory before the 12 th century, but Portugal maintained a remarkable stability since that period without major population movements into the country until the late 20th century, except perhaps, that of the slave trade between the 15th and 18th centuries (Serrão, 1992). Nonetheless, there is no evidence for a differential genetic contribution from such population movements to distinct areas of the country between the 12th and early 20th centuries, except for the southern region of Alentejo (Beleza et al., 2006). In addition, any explanation for differences in size between the Leiria and Lisbon samples that relies partially on such population movements, which are very imprecise and imperfect measures of genetic change at best, is not useful given the enormous plasticity of human growth in response to environmental change (Bogin et al., 2001; Bogin and Rios, 2003). For example, contemporary Portuguese have showed a remarkable change in height over the last 40 years (Padez, 2003; Cardoso, 2008) comparable with what other populations experienced as a consequence of a positive secular trend. From military conscript data, which represent the entire country, it was shown that the Portuguese male population increased in stature about $8.93 \mathrm{~cm}$ between 1904 and 2000, with the greatest gain occurring since the 1960s and 1970s (Padez, 2003). A genetic explanation cannot account for the rapid height change in such a little time. The reason for this change lies, instead, in a collective of environmental factors, from improved quantity and quality of nutrition, to lessening of infectious diseases, which were triggered by political, economical, and social changes, that increased family incomes, provided easy access to better nutrition and health care and sanitary living conditions (Padez, 2003; Cardoso, 2008). On these grounds, we are also inferring different environmental conditions between the medieval and early 20th century samples if growth differences are detected between them.

\section{RESULTS}

Compared with the nineteenth century sample from Belleville, the Lisbon children show a mean growth deficit of $-1.6 z$-scores $(\mathrm{SD}=1.50)$, whereas the Leiria children show a mean growth deficit of $-2.0 z$-scores (SD $=$ 1.26). Although there is a tendency for Leiria to show greater growth retardation, differences between the samples are not statistically significant $(t=1.42 ; \mathrm{df}=88 ; P$ $=0.1554$ ). Both samples, therefore, show a significant growth deficit. Adult data also show a deficit in femur length in the Leiria and Lisbon samples when compared with the Belleville sample. When compared with the Belleville adults (females: mean $=429.5 \mathrm{~mm}, \mathrm{SD}=22.80$; males: mean $=464.0, \mathrm{SD}=22.76$ ), only the Leiria females do not show significantly shorter femora $(t=$ $0.93 ; \mathrm{df}=111 ; P=0.3536)$, whereas Leiria males $(t=$ 2.78; $\mathrm{df}=149, P=0.0062)$, Lisbon females $(t=5.59$; $\mathrm{df}$ $=146, P=0.0000)$ and males $(t=6.21$; $\mathrm{df}=178, P=$ $0.0000)$, all show significantly reduced femur length.

Medieval Leiria adults, however, have significantly longer femora than early 20th century Lisbon adults. Mean maximum femur length is $424.2 \mathrm{~mm}(\mathrm{SD}=18.54)$ for Leiria females and $451.3 \mathrm{~mm}(\mathrm{SD}=19.48)$ for Leiria males, and $408.4 \mathrm{~mm}(\mathrm{SD}=20.10)$ for Lisbon females and $441.5 \mathrm{~mm}(\mathrm{SD}=22.77)$ for Lisbon males. Both the females $(t=2.93 ; \mathrm{df}=68 ; P=0.0046)$ and the males $(t=1.98 ; \mathrm{df}=85 ; P=0.0504)$ differ significantly between the two samples. Comparatively, when the growth of children in both samples is contrasted, the Leiria children are not significantly delayed or advanced relative to the Lisbon children. Table 2 presents the regression coefficients of the Leiria and Lisbon samples, when femur length is regressed on tooth length, and the ANCOVA test results. Data in Table 2 show homogeneity of slopes and elevations in all SGPs at the 0.05 probability level. This means that the Leiria and Lisbon regression lines do not differ significantly, regardless of the 
TABLE 3. Comparison between Leiria (medieval) and Lisbon (early 20th century) regression coefficients when femur diaphyseal length is regressed on dental age

\begin{tabular}{|c|c|c|c|c|c|c|c|c|c|c|c|}
\hline $\bar{N}$ & $A$ & SE (A) & $b$ & $\mathrm{SE}(\mathrm{b})$ & $c$ & $\mathrm{SE}(\mathrm{c})$ & $d$ & $\mathrm{SE}(\mathrm{d})$ & $e$ & $\mathrm{SE}(\mathrm{e})$ & $r^{2}$ \\
\hline \multicolumn{12}{|c|}{ Leiria sample } \\
\hline & \multicolumn{10}{|c|}{ Lisbon sample } & 0.97 \\
\hline 68 & 77.29 & 7.06 & 46.90 & 8.82 & -6.61 & 3.18 & 0.66 & 0.41 & -0.02 & 0.01 & 0.96 \\
\hline
\end{tabular}

Femur diaphyseal length is estimated from a fourth degree polynomial: $y=A+b \times x+c \times x^{2}+d \times x^{3}+e \times x^{4}$. The standard errors (SE) of the coefficients and the coefficient of determination $\left(r^{2}\right)$ are shown. The homogeneity of the regression coefficients $(F$ $=0.87 ; P=0.3833)$ and of the elevations $\left(F^{\prime}=1.70 ; P=0.0953\right)$ is compared by a polynomial analysis of covariance (ANCOVA).

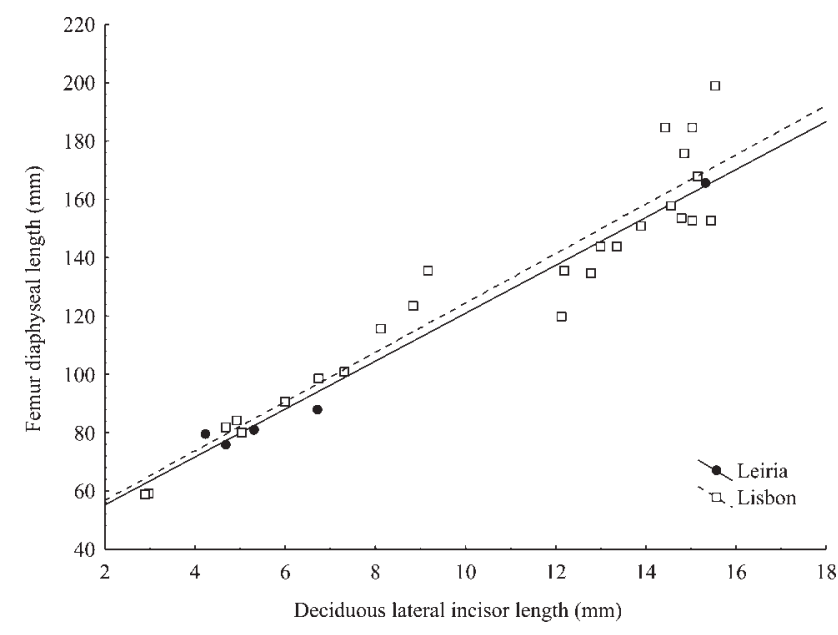

Fig. 1. Data points and regression lines obtained from the Leiria (medieval) and Lisbon (early 20th century) samples, where femur diaphyseal length is regressed on deciduous lateral incisor length.

tooth length utilized. Only at the 0.10 probability level did one regression line differ between samples in the slopes (first permanent molar) and one regression line differed in the elevations (first permanent premolar). When considering the standard error of the regression estimates, they are almost always greater in the Lisbon than in the Leiria sample, which is a reflection of less variation being sampled in Leiria. As a result, the Lisbon regression lines include wider $95 \%$ confidence intervals, which encompass a large amount of the Leiria regression 95\% confidence bands. These results, however, strongly suggest that the Leiria and Lisbon children do not differ in growth status before puberty. The polynomial ANCOVA results for the comparison between the two samples' overall SGPs using dental age (Table 3 , confirm that growth of Leiria children is not significantly different from that of Lisbon children.

Figures 1-3 were chosen to illustrate the relationship between femur growth and tooth length (age) in the Leiria and Lisbon samples. In all figures, there are no differences between samples when femur length is plotted against age. Overall, there is only a small tendency for the Leiria regression line to be drawn below the Lisbon regression line. This may be suggestive of a growth deficit in the Leiria sample, but the ANCOVA results indicate otherwise. The various graphs of femur length plotted against tooth length represent various individuals at different ages, from birth to around 12 years of age. Some individuals had one tooth measured whereas others had more than one and thus are represented in

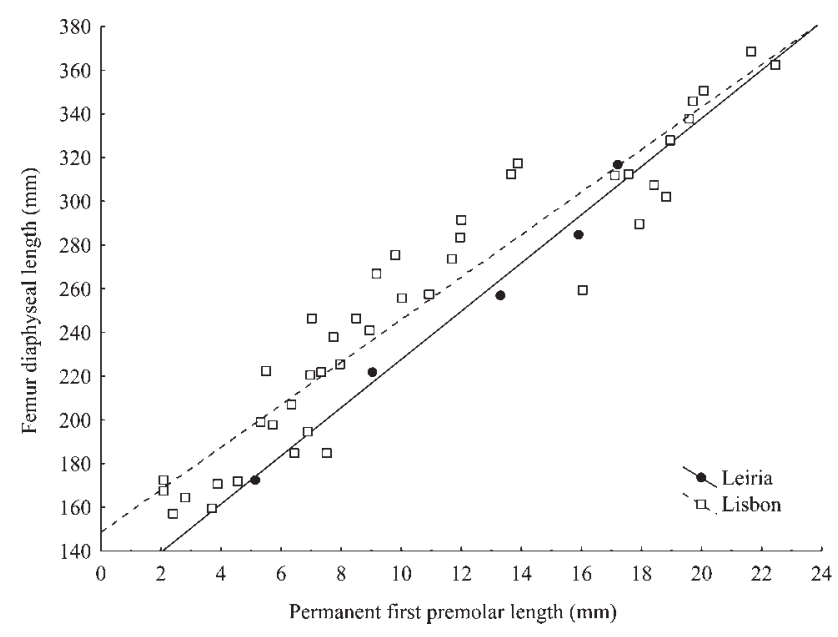

Fig. 2. Data points and regression lines obtained from the Leiria (medieval) and Lisbon (early 20th century) samples, where femur diaphyseal length is regressed on permanent first premolar length.

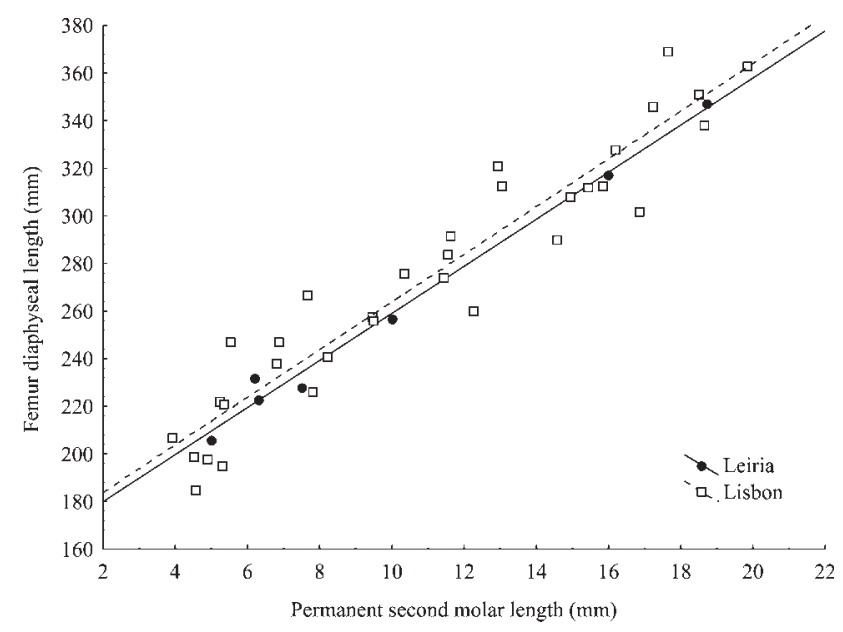

Fig. 3. Data points and regression lines obtained from the Leiria (medieval) and Lisbon (early 20th century) samples, where femur diaphyseal length is regressed on permanent second molar length.

more than one of the figures and regression equations. Figure 4 illustrates the SGP when femur length is regressed on dental age estimates, using the entire samples. Except during middle childhood, where the Leiria regression line is drawn below the Lisbon regression line, growth in the two samples does not seem to differ, 


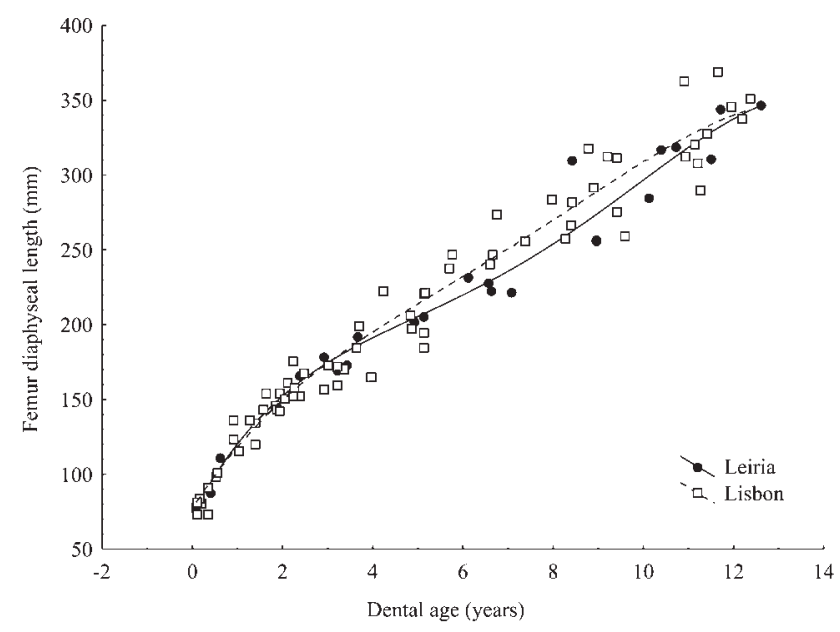

Fig. 4. Overall skeletal growth profiles of the Leiria (medieval) and Lisbon (early 20 th century) samples, where femur diaphyseal length is plotted against dental age. The regression line depicted represents a fourth-degree polynomial adjustment.

thus substantiating and strengthening the results obtained with the femur length by individual tooth SGPs. These data show that until 12 years of age, the increase in femur length in the Lisbon and Leiria samples is quite similar. However, significantly greater femur length in the Leiria adults is strongly suggestive of differences in growth between the samples during adolescence.

\section{DISCUSSION Skeletal growth profiles}

Five important methodological considerations have to be made with respect to the observed pattern of growth between the medieval and modern samples. First, because age estimators are identical in both samples, errors in dental age assessment cannot be an explanation for the observed results. Second, several authors (Johnston, 1962; Buikstra and Cook, 1980; Wood et al., 1992) have pointed out that growth patterns in skeletal samples which do not represent the growth of normal, healthy children, but instead would represent a deficit relative to the population norm. However, given that neither sample is comprised of living children, this criticism is unlikely to hold for explaining the observed similarities and/or differences. Third, although it can be argued that a SGP built with estimated dental ages using each entire sample would suffice to compare growth between the Leiria and Lisbon samples, our goal was to present a novel approach to comparing growth data. This new approach takes advantage of the near-linear relationship of femur with individual tooth length and can simplify the statistical comparison between different samples. The main limitation with this approach to growth in skeletal samples is that because SGPs are constructed tooth by tooth, they tend to decrease the available sample size significantly, thus creating difficulties in the detection of statistically significant differences. Fourth, although the sample sizes for the Leiria sample are somewhat low, it represents one of the largest samples of preadolescent skeletons from one single Portuguese archaeological site. Accordingly, we offer a tentative first analysis of growth differences between medieval and early 20th century Portuguese populations and infer changes in the environments for human growth. Last, this study is, by necessity, cross-sectional in nature and these are able to provide a lower level of evidence of causation.

The expectation of greater growth deficit in early 20th century Lisbon, as a consequence of poor living conditions compared with the Middle Ages, was partially met, but only in adolescence. The late medieval children from Leiria were found to be neither delayed nor advanced in growth of femur length compared to the early 20th century children from Lisbon. When $z$-scores and SGPs are compared between both samples, results show that, although the Leiria subadults tend to show a slighter deficit in growth, the difference is never statistically significant. Although some SGPs could not be compared when built with the length of the deciduous central incisor or of the permanent third molar, second premolar, and lateral incisor, there is an overall consistent pattern. The various SGPs by tooth length represent different children at various ages, from approximately birth to 12 years of age and, therefore, support the assertion that growth status does not differ between samples from infancy to late childhood. This pattern is strengthened by the results of the second approach, where femur length was plotted against an overall dental age. On the other hand, the Leiria adults were found to have significantly longer femora than the Lisbon adults, which is suggestive of a recovery in femur length during adolescence in medieval youths. Neither sample, however, can be considered to represent optimal rates of growth as both samples of children show significant growth deficits compared with a nineteenth century better-nourished population from North America (Saunders et al., 1993). The primary factor leading to the overall reduced adult femur length and, by implication, short adult stature, in these two populations is the growth retardation already present during childhood, as shown by the $z$-score values. Therefore, environmental circumstances during childhood seem to have been unfavorable in both samples, but during adolescence conditions may have changed placing Lisbon at greater disadvantage.

The difference observed between the adults and subadults of both samples could arise if the Lisbon sample comprises a greater proportion of girls or the Leiria sample a greater proportion of boys. Given that the growth of girls is more buffered against environmental insults (Stinson, 1985) and that the Lisbon adults have shorter femora than the Leiria adults, the Lisbon subadults can appear similar in size to the Leiria subadults if they comprise more girls than Leiria and hence show an overall pattern of growth which is less affected by poor living conditions. However, in the Lisbon sample there is actually only slightly more males than females, and in the Leiria sample, there is no reason to suspect that one sex would outnumber the other in such a way as to bias the results. The results could be also explained if the subadults and adults of the same sample come from different socioeconomic strata. If the Leiria subadults are of lower socioeconomic status than the adults, this could explain the difference between samples, given that the adults and subadults of the Lisbon sample do not seem to differ in their socioeconomic background, as inferred from the documentary records. But, as far as the authors are aware, there is no evidence for this differential socioeconomic representation. Even if the Leiria subadults were of lower socioeconomic condition than the adults, it 
would still lend support to the conclusion that the environment for growth was poorer in the early 20 th century than during the medieval period.

If we are left to conclude that the medieval period provided a better environment for human growth after puberty, what could explain the differences in growth during adolescence that can be inferred from comparing both samples? At the simplest level, these differences seem to indicate a greater potential for catch-up growth in the Leiria adolescents. Catch-up growth during adolescence is a common phenomenon in developing countries where prolongation of the growth period can make up for some of the earlier growth deficit (Satyanarayana et al., 1980, 1989; Kulin et al., 1982; Tanner, 1986; Golden, 1994; Martorell et al., 1994; Norgan, 2000; Coly et al., 2006). However, the marked growth retardation incurred in early childhood generally remains into adulthood. Stunting seems to be reduced if the environment is improved or if there is no further decline of an already unfavorable environment. If the medieval children from Leiria show a greater potential for catch-up growth compared with the modern children from Lisbon, we can conclude that a change in the environment must have occurred around puberty, which has resulted in a deterioration of the Lisbon adolescents' nutritional status, compared with that of the Leiria adolescents. We have already argued against a genetic explanation for differences in size between the two samples and suggest that the plastic ability of humans to adjust to changes in the environment is the likely cause of variability in human growth patterns which explains the differences between the samples.

\section{Environments for human growth}

For most of the early 20th century, prevailing social and living conditions in Portugal were those of the late 19th century. Living conditions were particularly difficult for the poor and working classes in Lisbon (Crespo, 1990), where overcrowding and unsanitary environments were generalized and health conditions were very poor. For example, a 1950s study on housing of the working class in Lisbon (Moreira, 1950) found that $43 \%$ of the families had no piped water, $69 \%$ had no electric power, and $81 \%$ had no toilet. Although, historically, the construction of piped sewerage systems were important for improving urban public health, by $1970,27 \%$ of the population in Lisbon still had no access to the public sewerage system (INE, 1970). It was only after the 1960s and 1970 s that the Portuguese population experienced major changes in exposure to, and treatment of, infectious disease, and in welfare (Sanches and Carvalho, 1983; Carreira, 1996; Veiga et al., 2004). Therefore, given that most individuals in the Lisbon sample were born between 1900 and 1950, they did not experience these recent environmental changes. Life in medieval Leiria would also have shared the perils of a premodern epidemiological profile, where infectious disease prevailed. Nonetheless, social support and health care was provided by various charity institutions of catholic inspiration who offered shelter, food, and some relief and medical assistance to the medieval poor of Leiria. The not so needy would also have access to the services of several professional health caretakers, such as physicians, surgeons and botanists (Gomes, 1999). People in Leiria also benefited from living in a less densely populated urban center, which provided some protection against aggra- vated sanitation problems and spread of communicable diseases, compared to Lisbon.

Given that growth in height is considered a proxy for long-term health and nutritional experience, as it reflects the synergetic difference between the accumulated intake of nutrients and use of energy in work and fighting infection (Floud, 1994; Steckel, 1995), it is hypothesized that, since health conditions of Leiria and Lisbon children were probably similar with respect to exposure to, and treatment of, infectious disease, differences in adolescent growth may have resulted from changes in physical labor, which have a negative impact on nutritional status. It is also unlikely that the disease environment has changed from childhood to adolescence in both samples, and thus it seems improbable that the difference in growth status at adolescence between the samples was caused by a differential decrease or increase in exposure to infectious disease. We suggest that it might have been the entering of Lisbon children into the labor market which might have triggered the environmental change responsible for reduced or absent catch-up growth, namely increased physical activity and risk of undernutrition. This rests on the notion that normal growth spurts during puberty and adolescence are adversely affected by increased manual labor and, as a consequence, by the poor nutrient intake which does not compensate for the energy diverted from growth to physical work. Growth velocities, and hence nutrient needs, are high during adolescence and, therefore, growth during this period is sensitive to a poor nutritional status (Bogin, 1999). There is one study, carried out in Japan, which demonstrates a difference of $4 \mathrm{~cm}$ in height between those who began work before the age of 14 and those who began after 18 years of age, whereas their height had been comparable at age 12 (Mendelievich, 1979). Findings in other studies (Satyanarayana et al., 1986; Hawamdeh and Spencer, 2001, 2003; Duyar and Özener, 2005) indicate that working children are behind in height when they are compared with their nonworking same-age peers living in similar conditions and that these differences are carried on to adult life (Satyanarayana et al., 1986; Duyar and Özener, 2005).

Findings in this study seem to suggest that when the Lisbon children entered the labor market, at about 12 years of age (Valente, 1986; Campinho, 1995), their net nutritional status may have decreased compared with the Leiria children and thus may explain why the potential for catch-up growth is lower or absent in Lisbon. Physical work did not affect the body height per se, as they were already stunted at infancy and childhood, but diminished the potential for recovery in height during the adolescent years, by diverting available energy in the diet away from growth. In Leiria, however, net nutritional status seems to have allowed for some recovery in size by prolongation of the growth period. Historical data from Medieval and early 20th century Portugal seems to lend support to this hypothesis. In Lisbon, a large percentage of the local industrial labor force was comprised of children. In some industries, children made up almost $25 \%$ of the work force (Rosas, 1994). Although most factories and services admitted apprentices in their facilities, these children and/or adolescents were frequently subjected to a harsh, heavy, and demanding work environment, serving as unskilled work and exploited for their labor (Cândido et al., 1965). These children worked for meager salaries to help support their poor families, who lived in unsanitary and crowded 
living conditions in working class overpopulated neighborhoods (Rosas, 1994). It was only after the 1950s and 1960s that Portugal started to experience a transformation, with stricter child labor laws, and an overall improvement in the standard of living. Comparatively, medieval children were incorporated into rural work from an early age, but provided supplementary labor only to help support their families and were young apprentices of a series of family activities, such as manufacture, crafts, and services (Oliveira, 2007). The conditions of children employed in family activities may have been better, because the effort, fatigue, and dangers to which they are frequently exposed are balanced in part by the care and attention they receive from other family members (Mendelievich, 1979). We are not implying that the lives of Leiria adolescents were not harsh and perilous, but instead that they were not as difficult as the lives of Lisbon adolescents, as reflected in their different growth status.

Interestingly, Saunders et al. (1993) noticed a phenomenon similar to what we describe here. The Belleville SGP exhibit a relationship similar to the modern Denver growth profile up to 12 years, but as adults the Denver sample shows longer femora than the Belleville sample. Saunders et al. (1993) suggest as a possible explanation that the Denver sample had an earlier and longer adolescent growth, but they do not elaborate on this any further. Since the prolongation of the growth period tends to reflect a compensation for an earlier growth deficit (Satyanarayana et al., 1980, 1989; Kulin et al., 1982; Tanner, 1986; Golden, 1994; Martorell et al., 1994; Norgan, 2000; Coly et al., 2006), we would suggest, instead, that the Denver sample simply had a greater growth rate during adolescence. However, any environmental explanation for this difference would be purely speculative, given our lack of knowledge about the details of the historical and cultural context of the Belleville sample. Other results similar to those of this study have been infrequently reported, with the exception of the works carried out by Steckel (1986) and Lewis (2002). Using records of African-American slave children anthropometrics, Steckel was able to show that slaves were severely stunted (undernourished) as children, but when slaves entered the labor force they caught-up, and became as tall or as taller as their African adult counterparts. Although net nutrition should have deteriorated for slaves at this time, there was in fact an improvement in the slave diet sufficient to offset the additional requirements of physical activity and to allow a small amount of catch-up growth during adolescence. This remarkable pattern of growth and dietary recommendations of owners supports Steckel's assertion that slaves were poorly fed as children but extraordinarily well fed as workers. Although neither the Lisbon nor the Leiria children experienced similar changes in their diets, Steckel's study shows that such environmental modifications at puberty can have tremendous effects on the growth of adolescents, when compared with the children. With respect to the relative better environment for human growth of medieval towns, Lewis (2002) found that early modern London children from Spitalfields were consistently shorter, showing a difference of up to $3 \mathrm{~cm}$ in femur length than their urban medieval counterparts from St. Helen-on-the-Walls, between birth and 12 years of age. Although in this study growth differences between the modern and medieval samples already began at birth, and not just since adolescence, this was attributed to the worse living conditions

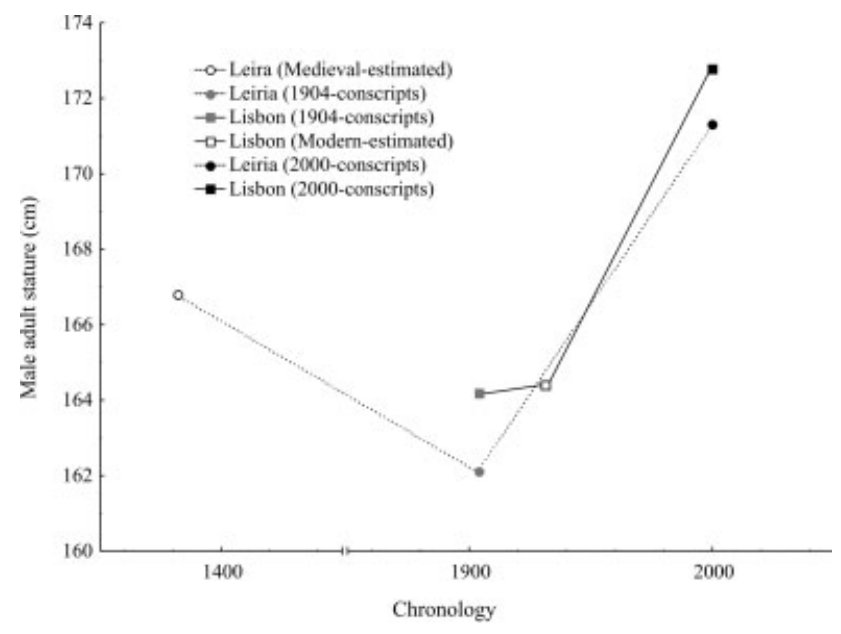

Fig. 5. Trends in male adult stature between the medieval period and the late 20th century in Leiria, and between the early and late 20th century in Lisbon. Leiria is represented by the circles, which are connected by a broken line. Lisbon is represented by the squares, which are connected by a solid line.

of the industrial London compared to the earlier medieval urban cities.

Results in this study show similar detrimental effects on adolescent growth of increased urbanization of Lisbon, compared with Leiria and, in general, imply that the early 20 th century in Lisbon provided at least similarly unfavorable environmental conditions than that of the late Middle Ages in Leiria, if not overall worse circumstances once children entered the labor market. This relative depression in living conditions at the early 20 th century, compared with the medieval period, is also illustrated in Figure 5. In this figure, conscript male stature from the Leiria and Lisbon areas in 1904 and 2000 are shown, compared with the estimated statures from mean male femur length of the medieval Leiria and the early 20 th century Lisbon samples. Stature in this figure was estimated from Mendonça's (2000) male formulae. The mean year at age 18 in the Lisbon sample (1931) and the mid-point of the Leiria sample chronology (1382) are used to plot the stature estimations. A remarkable increase in conscript stature can be seen from the early (1904) to the late 20th (2000) century and the stature estimation for the Lisbon sample is what would be expected given the birth dates of the this sample, the general secular trend in Portugal, and the greater secular effect later in the century (Padez, 2003). On the other hand, this figure clearly shows the reduced stature of the Lisbon males in 1904 compared with the Leiria medieval males, and a further reduction of the Leiria males also in 1904. This is an additional and strong indication of the depressed living conditions of the early 20th century in Portugal compared with the medieval period. These results suggest, indirectly, that it was industrialization and increased urbanization in the early 20th century, that had a detrimental effect on the growth of the more modern children, more so than the supposedly miserable peasant living conditions of the medieval period. In other words, the "Dark Ages" may not have been so dark once we compare the overall living conditions between these two periods and the two urban centers. Indeed, the title of this paper could also have been "the not-so-prosperous industrial period in Portugal." 
Although, there was no real industrial revolution in Portugal, the city of Lisbon supported important small industries and a large service sector, which promoted an increase in population density, where living conditions for the working classes were frequently crowded, unsanitary, and offered increased risks of infection, malnutrition, probably not unlike the circumstances of medieval Leiria, except perhaps in child labor practices which may have placed Lisbon adolescents at greater risk of undernutrition.

\section{CONCLUSION}

This study compared the growth status of late medieval children with that of early 20 th century urban/industrial children from Portugal. Because the growth of children provide such a good index of the quality of the environment in which they live and, as consequence, of the overall population, the results in this study strongly suggest similarly unfavorable environmental conditions in early 20th century Lisbon compared with medieval Leiria. This stems from the fact that growth of medieval children did not differ significantly from growth of modern children. However, because medieval adolescents may have had more opportunities for catch-up growth, since they had longer femora as adults; distinct child labor practices in both periods may have caused a decline in early 20 th century children living conditions. Although medieval Leiria and early 20th century Lisbon may not have differed in the overall disease environment, early 20th century Lisbon provided a poorer environment for human growth during adolescence as a consequence of exhausting work being added to children's burdens of disease and poor diet, when they entered the labor market. Although the lives of medieval children may have been as difficult, they were not further deteriorated after puberty. The application of these hypotheses to the patterns of childhood and adolescent growth of these medieval and late modern Portuguese children is speculative, but even scarce documentary data seems to correlate with higher rates of child labor, greater chronic mild-to-moderate undernutrition, and generally unfavorable environment for growth in Lisbon compared with Leiria, but only in the adolescent period.

\section{ACKNOWLEDGMENTS}

We would like to express our gratitude to the anonymous reviewers and to the editor for their comments and suggestions, which helped to improve the paper significantly. We would also like to thank Dr. Barry Bogin's comments and corrections to an earlier version of this paper and the late Dr. Shelley Saunders for providing us the adult data from the Belleville skeletal sample. Thanks to the Bocage Museum for institutional support and the Leiria municipality for providing the opportunity to study the São Martinho sample.

\section{LITERATURE CITED}

Ariès P. 1962. Centuries of childhood. A social history of family life. New York: Vintage Books.

Baptista L, Rodrigues T. 1995. Dinâmica populacional e densificação urbana: o município de Lisboa nos séculos XIX e XX. In: Câmara Municipal de Lisboa, editor. Actas do I colóquio temático - o município de Lisboa e a Dinâmica Urbana (Séculos XVIXX). Lisboa: Câmara Municipal de Lisboa. p 267-292.
Beleza S, Gusmão L, Lopes A, Alves C, Gomes I, Giouzeli M, Calafell F, Carracedo A, Amorim A. 2006. Micro-phylogeographic and demographic history of Portuguese male lineages. Ann Hum Genet 70:181-194.

Bogin B. 1999. Patterns of human growth. Cambridge: Cambridge University Press.

Bogin B, Kapell M, Varela Silva MI, Orden AB, Smith PK, and Loucky J. 2001. How genetic are human body proportions? In: Dasgupta P, Hauspie R, editors. Perspectives in human growth, development, and maturation. Dordrecht: Kluwer Academic Publishers. p 205-221.

Bogin B, Rios L. 2003. Rapid morphological change in living humans: implications for modern human origins. Comp Biochem Physiol A 136:71-84.

Buikstra JE, Cook DC. 1980. Paleopathology: an American account. Ann Rev Anthrop 9:433-470.

Buschang PH. 1982. Differential long bone growth of children between two months and eleven years of age. Am J Phys Anthropol 58:291-295.

Campinho A. 1995. Regime jurídico do contrato de trabalho de menores. História, legislação, anotações e convenções internacionais. Braga: Editora Correio do Minho.

Cândido LM, Antunes AR, and Loff P. 1965. A aprendizagem nas empresas. Lisboa: Ministério das Corporações.

Cardoso HFV. 2006. The collection of identified human skeletons housed at the Bocage Museum (National Museum of Natural History), Lisbon, Portugal. Am J Phys Anthropol 129:173176.

Cardoso, HFV. 2007a. Environmental effects on skeletal versus dental development: using a documented subadult skeletal sample to test a basic assumption in human osteological research. Am J Phys Anthropol 132:223-233.

Cardoso HFV. 2007b. Accuracy of developing tooth length as an estimate of age in human skeletal remains: the deciduous dentition. Forensic Sci Int 172:17-22.

Cardoso HFV. 2008. Secular changes in body height and weight of Portuguese boys over one century. Am J Hum Biol. 20:270 277.

Carreira HM. 1996. Saúde. In: Barreto A, editor. A situação social em Portugal 1960-1995. Lisboa: Imprensa de Ciências Sociais. p 409-421.

Coly AN, Milet J, Diallo A, Ndiaye T, Bénéfice E, Simondon F, Wade S, Simondon KB. 2006. Preschool stunting, adolescent migration, catch-up growth, and adult height in young Senegalese men and women of rural origin. J Nutr 136:2412-2420.

Crespo J. 1990. A história do corpo. Lisboa: Difel.

de Beer H. 2004. Observations on the history of Dutch physical stature from the Late-Middle Ages to the present. Econ Hum Biol 2:45-55.

Duyar I, Özener B. 2005. Growth and nutritional status of male adolescent laborers in Ankara, Turkey. Am J Phys Anthropol 128:693-698.

Floud R. 1994. The heights of Europeans since 1750: a new source for European economic history. In: Komlos J, editor. Stature, living standards and economic development: essays in anthropometric history. Chicago: The University of Chicago Press. p 9-24.

Fogel RW. 1986. Physical growth as a measure of the economic well-being of populations: the eighteenth and nineteenth centuries. In: Falkner F, Tanner JM, editors. Human growth: a comprehensive treatise. New York: Plenum Press. p 263-281.

Garcia, S. 2007. Maleitas do corpo em tempos medievais. Indicadores paleodemográficos, de stresse e paleopatológicos numa série osteológica urbana de Leiria, Ph.D. in Biological Anthropology. Coimbra: Departamento de Antropologia, Universidade de Coimbra.

Giner S. 1982. Political economy, legitimation and the state in Southern Europe. Br J Sociol 33:172-199.

Golden MHN. 1994. Is complete catch-up possible for stunted malnourished children? Eur J Clin Nutr 48(Suppl. 1):S58S71.

Gomes SA. 1990. A Praça de São Martinho de Leiria do século XII à reforma de 1546. Mundo da Arte, Revista de Arte, Arqueologia e Etnografia. II Série:57-78. 
Gomes SA. 1999. Higiene e saúde na Leiria medieval. In: Câmara Municipal de Leiria, editors. III Colóquio sobre a história de Leiria e da sua região. Leiria: Câmara Municipal de Leiria. p 9-43.

Gonçalves I. 2004. Entre a abundância e a miséria: as práticas alimentares da Idade Média portuguesa. In: Andrade AA, Silva JCV da, editors. Estudos medievais. quotidiano medieval: imaginário, representação e práticas. Lisboa: Livros Horizonte. p 43-65.

Hawamdeh H, Spencer N. 2001. Work, family socioeconomic status, and growth among working boys in Jordan. Arch Dis Child 84:311-314.

Hawamdeh H, Spencer N. 2003. The effects of work on the growth of Jordanian boys. Child Care Health Dev 29:167-172.

Hoppa RD. 1992. Evaluating human skeletal growth: an AngloSaxon example. Int J Osteoarchaeol 2:275-288.

Hoppa RD. 2000. What to do with long bones: toward a progressive palaeoauxology. Anthropologie 38:23-32.

INE. 1970. Censos 1970: XI recenseamento geral da população, I recenseamento geral da habitação. Lisboa: Instituto Nacional de Estatística.

Johnston FE. 1962. Growth of the long bones of infant and young children at Indian Knoll. Am J Phys Anthropol 20:249254.

Johnston FE, Zimmer LO. 1989. Assessment of growth and age in the immature skeleton. In: Iscan MY, Kennedy KAR, editors. Reconstruction of life from the skeleton. New York: Alan R. Liss, Inc. p 11-21.

Kemkes-Grottenthaler A. 2005. The short die young: the interrelationship between stature and longevity. Evidence from skeletal remains. Am J Phys Anthrop 128:340-347.

Kulin HE, Bwibo N, Mutie D, Santner SJ. 1982. The effect of chronic childhood malnutrition on pubertal growth and development. Am J Clin Nutr 36:527-536.

Lewis ME. 2002. Impact of industrialization: comparative study of child health in four sites from medieval and postmedieval England (A.D. 850-1859). Am J Phys Anthropol 119:211223.

Lima DLC. 1736. Geografia historica de todos os estados soberanos da Europa. Tomo II. Lisboa: Off. de Joseph Antonio da Sylva.

Liversidge HM, Dean MC, Molleson TI. 1993. Increasing human tooth length between birth and 5.4 years. Am J Phys Anthropol 90:307-313.

Liversidge HM, Molleson TI. 1999. Developing permanent tooth length as an estimate of age. J Forensic Sci 44:917-920.

Maat G. 2005. Two millennia of male stature development and population health and wealth in the Low Countries. Int $\mathrm{J}$ Osteoarch 15:276-290.

Maia R. 2001. Descontinuidades e permanências nas estruturas da economia e da sociedade portuguesa nos últimos sessenta anos. In: Associação Portuguesa de Sociologia, editor. Actas do IV Congresso Português de Sociologia. Coimbra: Associação Portuguesa de Sociologia. Available at: http:/www.aps.pt/ ivcong-actas/Acta136.PDF. Accessed on June 1, 2005.

Magalhães J. 1993. As estruturas de produção agrícola e pastoral. In: Mattoso J, editor. História de Portugal: no alvorecer da modernidade, vol. 3. Lisboa: Círculo de Leitores. p 243282.

Maresh MM. 1970. Measurements from roentgenograms. In: McCannon RW, editor. Human growth and development. Springfield: Charles C Thomas Publisher. p 157-188.

Martorell R, Khanl LK, and Schroederet DG. 1994. Reversibility of stunting: epidemiological findings in children from developing countries. Eur J Clin Nutr 48(Suppl. 1):S45-S57.

Mattoso J. 1993. 1096-1325: a formação da nacionalidade no espaço Ibérico. In: Mattoso J, editor. História de Portugal: a monarquia feudal (1096-1480), vol. 2. Lisboa: Círculo de Leitores. p 11-312.

Mays S. 1999. Linear and appositional long bone growth in earlier human populations: A case study from mediaeval England. In: Hoppa RD, Fitzgerald MC, editors. Human growth in the past: studies from bones and teeth. Cambridge: Cambridge University Press. p 290-321.

Mendelievich E. 1979. Child labour. Int Labour Rev 118:557-568.
Mendonça M. 2000. Estimation of height from the length of long bones in a Portuguese adult population. Am J Phys Anthropol 112:39-48.

Moreira MV. 1950. Problemas da habitação (ensaios sociais). Lisboa: Minerva.

Norgan NG. 2000. Long-term physiological and economic consequences of growth retardation in children and adolescents. Proc Nutr Soc 59:245-256.

Oliveira AR. 2007. A criança na sociedade medieval Portuguesa. Lisboa: Teorema.

Padez C. 2003. Secular trend in stature in the Portuguese population (1904-2000). Ann Hum Biol 30:262-278.

Paúl A. 1945. Caracteres demográficos do distrito de Lisboa. Revista do Centro de Estudos Demográficos 1:81-104.

Pearson K. 1899. Mathematical contributions to the theory of evolution: on the reconstruction of the stature of prehistoric races. Philos Trans R Soc Lond (Ser A) 192:169-244.

Pinhasi R, Shaw P, White B, Ogden AR. 2006. Morbidity, rickets, and long bone growth in post-medieval Britain-a crosspopulation analysis. Ann Hum Biol 33:372-389.

Pinhasi R, Teschler-Nicola M, Knaus A, Shaw P. 2005. Crosspopulation analysis of the growth of long bones and the os coxae of three early mediaeval Austrian populations. Am J Hum Biol 17:470-488.

Rosas F. 1994. Portugal e o estado novo (1926-1974). História de Portugal, Vol. 7. Lisboa: Círculo de Leitores.

Ruff CB. 2002. Variation in human body size and shape. Ann Rev Anthropol 31:211-232.

Ruff CB. 2007. Body size prediction from juvenile skeletal remains. Am J Phys Anthropol 133:698-716.

Sanches N, and Carvalho MC. 1983. Vacinações. Lisboa: Edições Sandoz.

Satyanarayana K, Krishna TP, Rao BSN. 1986. Effect of early childhood undernutrition and child labour on growth and adult nutritional status of rural Indian boys around Hyderabad. Hum Nutr Clin Nutr 40:131-139.

Satyanarayana K, Naidu AN, Rao BSN. 1980. Adolescent growth spurt among rural Indian boys in relation to their nutritional status in early childhood. Ann Hum Biol 7:359365.

Satyanarayana K, Radhaiah G, Mohan KRM, Thimmayamma BVS, Rao NP, Rao BSN. 1989. The adolescent growth spurt of height among rural Indian boys in relation to childhood nutritional background: an 18 year longitudinal study. Ann Hum Biol 16:289-300.

Saunders SR. 1992. Subadult skeletons and growth related studies. In: Saunders SR, Katzenberg MA, editors. Skeletal biology of past peoples: research methods. New York: WileyLiss. p 1-20.

Saunders SR. 2000. Subadult skeletons and growth related studies. In: Katzenberg MA, Saunders SR, editors. Biological anthropology of the human skeleton. New York: Wiley. p 135-162.

Saunders SR, Hoppa R, Southern R. 1993. Diaphyseal growth in a nineteenth century skeletal sample of subadults from St Thomas' Church, Belleville, Ontario. Int J Osteoarch 3:265281.

Schell LM. 1989. Community health assessment through physical anthropology: auxological epidemiology. Hum Org 45:321327.

Serrão J. 1992. Dicionário de história de Portugal, Volume 2. Porto: Figueirinhas.

Shahar S. 1990. Childhood in the Middle Ages. London: Routledge.

Steckel RH. 1986. A peculiar population: the nutrition, health, and mortality of American slaves from childhood to maturity. J Econ Hist 46:721-741.

Steckel RH. 1995. Stature and standard of living. J Econ Lit 33:1903-1940.

Steckel R. 2004. New light on the "Dark Ages": the remarkably tall stature of Northern European men during the Medieval era. Soc Sci Hist 28:211-229.

Stinson S. 1985. Sex differences in environmental sensitivity during growth and development. Yearbk Phys Anthropol 28:123-147. 
Susanne C. 1984. Living conditions and secular trend. Stud Hum Ecol 6:93-99.

Tanner JM. 1982. The potential of auxological data for monitoring economic and social well-being. Soc Sci Hist 6:571-581.

Tanner JM. 1986. Growth as a target-seeking function: catch-up and catch-down growth in man. In: Falkner F, Tanner JM, editors. Human growth: a comprehensive treatise, Vol. 1. Developmental biology: prenatal growth. New York: Plenum Press. p 167-179.

Tanner JM. 1989. Fetus into man: physical growth from conception to maturity. Cambridge, MA: Harvard University Press.
Trotter M, Gleser G. 1952. Estimation of stature from long bones of American Whites and Negroes. Am J Phys Anthropol 10:463-514.

Valente A. 1986. A problemática do trabalho de menores em Portugal. Lisboa: Textos de Apoio.

Veiga TR, Moreira MJG, Fernandes AA. 2004. Social changes and better health conditions of the Portuguese population 1974-2000. Hygiea Internationalis 4:255-276.

Wood JW, Milner GR, Harpending HC, Weiss KM. 1992. The osteological paradox: problems from inferring prehistoric health from skeletal samples. Curr Anthropol 33:343-370. 